\title{
PENGARUH PROFITABILITAS, LEVERAGE, LIKUIDITAS, UKURAN PERUSAHAAN DAN KEBIJAKAN DIVIDEN TERHADAP NILAI PERUSAHAAN
}

\author{
Regia Rolanta ${ }^{1}$, Riana R Dewi ${ }^{2}$, Suhendro $^{3}$ \\ Program Studi Akuntansi, Fakultas Ekonomi, Universitas Islam Batik Surakarta ${ }^{1,2,3}$ \\ regiarolanta77@gmail.com \\ Penulis untuk Korespondensi/E-mail: regiarolanta77@gmail.com
}

\begin{abstract}
This study aimed to analyze the effect of profitability, leverage, liquidity, company size and dividend policy on firm value in the Consumer Goods Industry Sector Companies listed on the Stock Exchange in 2015-2018. In this study the Company Values measured using the Price to Book Value (PBV). This research method using descriptive analysis. The technique used is purposive sampling technique, so found 14 Consumer Goods Industry Sector Companies listed on the Stock Exchange from 2015 to 2018 period. The analysis used is multiple linear regression analysis. The results of this study showed that the variables of profitability, liquidity, and dividend policy affects the value of the company, while the company size and leverage variables do not affect the value of the company.
\end{abstract}

Keywords: ROA, DAR, $C R, P B V$.

\section{PENDAHULUAN}

Di negara Indonesia yang berkembang ini, semua perusahaan harus mampu bersaing untuk mempertahankan keberadaanya. Perusahaan yang telah mampu bersaing untuk memaksimalkan atau meningkatkan nilai perusahaan supaya investor berminat menanam saham pada perusahaan tersebut. Nilai perusahaan didefinisikan sebagai penilaian dari investor terhadap tingkat keberhasilan perusahaansetelah melihat tingkat harga saham perusahaan (Sambora, 2014).

Profitabilitas merupakan kemampuan untuk mengahasilkan perusahaan laba, perusahaan yang memiliki pengembalian yang tinggi atas investasi akan menggunakan utang yang relatif kecil. Tingkat pengembalian yang tinggi akan bisa untuk membiayai sebagian besar kebutuhan pendanaan dengan dana yang dihasilkan perusahaan internal Blinch, dkk (2011). Penelitian ini mengunakan pengukuran Return on Asset (ROA) sebagai alat ukur perusahaan berdasarkan tingkat equity atau bisa juga dgunakan perusahan untuk mengembalikan investasi dari investor.
Leverage yang semakin besar menunjukan resiko investasi yang semakin besar. Perusahaan yang memiliki rasio leverage yang rendah memiliki risiko leverage yang lebih kecil. Dengan tingginya nilai rasio leverage maka menunjukan perusahaan tidak solvable, yang berarti total hutangnya lebih besar dari pada total asetnya. Karena leverage merupakan rasio yang menghitung seberapa jauh dana yang disediakan oleh kreditur, juga sebagai rasio yang membandingkan total hutang terhadap keseluruhan aset suatu perusahaan, maka apabila investor melihat perusahaan dengan aset yang tinggi maka dengan itu resiko leverage tinggi Siahaan, dkk (2016).

Likuiditas menggambarkan kemampuan perusahaan untuk memenuhi kewajiban jangka pendeknya. Kemampuan seseorang atau perusahaan untuk memenuhi kewajiban atau utang yang harus segera dibayar dengan harta lancarnya. Rasio ini mengukur seberapa likuidnya suatu perusahaan. Jika perusahaan mampu memenuhi kewajibannya berarti perusahaan telah likuid. Untuk mengetahui perusahaan itu likuid atau tidak 
dapat diukur dengan cara membandingkan aktiva lancar dengan total pasiva lancar (utang jangka pendek). Menurut Gultom, dkk (2013) perusahaan yang mempunyai tingkat likuiditas yang tinggi menggambarkan perusahaan itu mampu memenuhi kewajibannya. Semakin tinggi likuid semakin menigkatkan nilai kepercayaan kreditur dalam memberikan dananya.

Ukuran perusahaan menggambarkan total aset yang dimiiki perusahaan. Semakin besar ukuran perusahaan maka banyak investor yang melirik dan menaruh kepercyaan pada perusahaan tersebut, sehingga dapat meningktkan nilai perusahaan. Nilai perusahaan yang meningkat dapat diketahui dari nilai total aktiva yang meningkat dibanding dengan jumlah hutang yang ada diperusahaan. Ukuran perusahaan dalam penelitian ini diukur dengan cara menghitung seberapa besar aset yang dimiliki oleh perusahaan tersebut. Aset yang dimiliki ini merupakan atau menggambarkan hak an kewajiban serta modal perusahaan.

Kebijakan deviden merupakan keputusan apakah laba laba yang dimiliki perusahaan dibagikan kepada pemegang saham atau dibiarkan atau ditahan dalam bentuk laba guna memperbaiki perusahaan yang akan datang, kebijakan deviden akan berdampak pada besarnya laba yang ditahan pada perusahaan yang merupakan sumber pembiayaan internal perusahaan untuk mengembangkan perusahaan menjadi lebih baik lagi dimasa mendatang. Menurut Priya \& Mohanasundari (2016) kebijakan deviden merupakan seperangkat aturan yang ditentukan perusahaan dalam menentukan banyak keuntungan yang dialokasikan untuk dibagikan kepada pemegang saham.

Pada penelitian ini bertujuan untuk meneliti secara parsial agar dapat mengetahui pengaruh profitabilitas, leverage, likuiditas, ukuran perusahaan dan kebijakan dividen terhadap nilai perusahaan pada perusahaan sub sektor food and beverage yang terdaftar di Bursa Efek Indonesia tahun 2014 sampai dengan 2018.

\section{KAJIAN TEORITIS}

\section{Teori Agensi}

Pada dasarnya agency theory merupakan hubungan agen (manajemen) dan pricipal (pemegang saham). Manajemen merupakan pihak yang dikontrak oleh pemegang saham untuk bekerja demi kepentingan pemegang saham Mulyani, dkk (2018) manajer diberi kekuasaan oleh pemegang saham yaitu membuat keputusan. Agen sebagai pembuat keputusan mempunyai kontrk untuk melaksanakan tanggung jawab tertentu memberikan laporannya kepada pihak prinsipal, sedangkan sebagai penilai informasi mempunyai kontrak untuk memberikan upah kepada agen. Hal ini menciptakan potensi konflik kepentingan yang dikenal dengan teori agen.

\section{Nilai Perusahaan}

Meningkatkan nilai perusahaan untuk memaksimalkan harga saham. Tujuan utama dalam manajemen perusahaan adalah pemegang saham dalam memaksimalisasi kekayaan dengan memaksimalkan harga saham perusahaan. Semakin meningkat kesejahteraan pemegang saham maka meningkat pula nilai perusahaan Barney.J (1991). Nilai perusahaan berarti harga yang bersedia dibayar oleh calon investor / calon pembeli apabila perusahaan itu dijual Husnan (2000). Nilai perusahaan diukur dengan rumus PBV (price book value)

$$
\text { Price Book Value }(P B V)=\frac{\text { Harga perlembar saham }}{\text { Nilai perlembar saham }}
$$

\section{Profitabilitas}

Profitabilitas merupakan kemampuan untuk mengahasilkan perusahaan laba, perusahaan yang memiliki pengembalian yang tinggi atas investasi akan menggunakan utang yang relatif kecil. Tingkat pengembalian yang tinggi akan bisa untuk membiayai sebagian besar kebutuhan pendanaan dengan dana yang dihasilkan perusahaan internal Blinch, dkk (2011).

Penelitian yang dilakukan Houston, (2006) rasio yang diukur untuk mengetahui perusahaan itu mampu menghasilkan laba selama periode tertentu dan muntuk melihat perusahaan tersebut beroperasi secara efisien Irawati, (2006). Profitabilitas merupakan hasil ahir dari sejumlah keputusan dan kebijakan manajemen perusahaan. Profitabilitas juga merupakan alat ukur kesuksesan suatu perusahaan dalam mengevaluasi kinerja manajer. Profitabilitas diukur dengan rumus ROA.

$$
\text { ROA }=\frac{\text { Laba Bersih Setelah Pajak }}{\text { Total Aset }}
$$

\section{Leverage}

Peneliti Kasmir, (2013) faktor yang penting dalam pendanaan adalah hutang. Tingginya nilai rasio leverage menunjukan bahwa perusahaan tidak solvable, yang berarti total utang lebih besar 
dari total asetnya. Leverage juga berarti untuk menghitung seberapa banyak dana yang dikeluarkan kreditur, rasio yang membandingkan total hutang terhadap total keseluruhan aset perusahaan. Apaila investor melihat leverage yang tinggi maka investor akan berpikir dua kali untuk berinvestasi diperusahaan tersebut. Leverage yang besar akan berdampak pada resiko investasiyang semakin besar pula. Perusahaan yang mempunyai leverage yang kecil makan memiliki resiko yang kecil juga.

Rasio leverage juga menunjukan besarnya modal yang berasal dari pinjaman yang berguna untuk biaya investasi dan opersional perusahaan. Besarnya pendanaan dari pinjaman dana maka akan meningkatkan resiko perusahaan Aryanto, dkk (2018). Leverage diukur dengan rumus DAR.

$$
D A R=\frac{\text { Total Hutang }}{\text { Total Aset }}
$$

\section{Likuiditas}

Likuiditas merupakan kemampuan perusahaan dalam memenuhi atau membayar kewajiban finacial jangka pendek. Ketidakmampuan perusahaan dalam membayar kewajiban jangka pendek diakibatkan beberapa faktor. Pertama, perusahaan tidak memiliki dana sama sekali. Kedua, perusahaan memiliki dana namun pada saat itu perusahaan tidak memiliki dana secara tunai sehingga perusahaan menunggu dalam jangka waktu tertentu untuk mencairkan dana dari berbagai aktiva seerti surat berharga, menagih piutang, dan menjual aktiva lainya Brigham, dkk (2010). Likuiditas diukur dengan rumus CR

$$
C R=\frac{\text { Total Aktifa Lancar }}{\text { Kewajiban Lancar }}
$$

\section{Ukuran Perusahaan}

Ukuran perusahaan mempunyai pengaruh yang berbeda terhadap nilai perusahaan pada perusahaan. Ukuran perusahaan dapat dilihat dari total aset yang dimiliki perusahaan tersebut, yang dapat berguan untuk operasi perusahaan. Jika didalam perusahaan mempunyai aset yang besar maka pihak manajemen leluasa dalam menggunakan aset tersebut. Kebebasan yang dimiliki manajemen ini sebanding dengan kekhawatiran yang dilakukan oleh pemilik atas aset. Ukuran perusahaan secara langsung mencerminkan tinggi rendahnya operasi atau aktivitas perusahaan Marfuah \& Nurlaela, (2017). Ukuran perusahaan diukur dengan rumus SIZE.

$$
\text { Size }=\operatorname{Ln}(\text { Total Aset })
$$

\section{Kebijakan Dividen}

Kebijakan deviden berarti keputusan untuk menentukan berapa besar bagian dari pendapatan perusahaan akan dibagikan kepada para pemegang saham dan dinvestasikan kembali atau ditahan dalam perusahaan.

Kebijakan deviden akan berdampak pada besarnya laba yang ditahan pada perusahaan yang merupakan sumber pembiayaan internal perusahaan untuk mengembangkan perusahaan menjadi lebih baik lagi dimasa mendatang. Menurut Priya \& Mohanasundari, (2016) kebijakan deviden merupakan seperangkat aturan yang ditentukan perusahaan dalam menentukan banyak keuntungan yang dialokasikan untuk dibagikan kepada pemegang saham. Kebijakan dividen diukur dengan rumus DPR.

$$
D P R=\frac{\text { Total Deviden }}{\text { Laba Bersih Setelah Pajak }}
$$

\section{Pengembangan Hipotesis}

Profitabilitas yang tinggi mencerminkan kemampuan perusahaan dalam mendapatkan keuntungan yang tinggi bagi pemegang saham. Dengan rasio profitabilitas yang tinggi makan akan menarik para investor untuk membeli atau menanamkan modalnya diperusahaan dan dengan ROA yang tinggi akan meningkatkan harga saham. Profitabilitas dapat diukur dengan ROA (Return on Assets) menggambarkan bahwa perusahaan efektif dalam memakai aktivanya dalam aktivitas operasi untuk membuahkan keuntungan. Maka akan menunjukan bahwa profitabilitas mempengaruhi nilai perusahaan. Penelitian Asmaul \& Ibnu, (2019) menunjukan bahwa variabel profitabilitas mempunyai pengaruh terhadap nilai perusahaan. Berdasarkan uraian tersebut maka dapat dirumuskan sebagai berikut:

\section{$H_{l}$ : Profitabilitas berpengaruh terhadap Nilai Perusahaan}

Tingginya rasio leverage menunjukan semakin besar dana yang disediakan kreditur. Hal tersebut akan membuat investor memikirkan jika mau berinvestasi diperusahaan yang memiliki nilai rasio leverage yang tinggi. Leverage dapat diukur denga DAR (Debt to Asset Ratio) menggambarkan sejauh mana kewajiban dapat ditutupi oleh aset. Penelitian Andriani, (2019) mengkasilkan bahwa 
variabel leverage mempunyai pengaruh terhadap nilai perusahaan. Berdasarkan uraian tersebut maka dapat dirumuskan sebagai berikut:

$\mathrm{H}_{2}$ : Leverage berpengaruh terhadap Nilai Perusahaan

Likuiditas merupakan kemampuan perusahaan dalam memenuhi kewajiban atau membayar utang jangka pendeknya. Likuiditas menjadi alat ukur untuk mengetahui aktivitas perusahaan karena likuiditas yang rendah berarti perusahaan sulit untuk mengembalikan kewajiban jangka pendeknya. Penelitian Andriani, (2019) menghasilkan bahwa variabel likuiditas mempunyai pengaruh terhadap nilai perusahaan. Berdasarkan uraian tersebut maka dapat dirumuskan sebagai berikut:

$H_{3}$ : Likuiditas berpengaruh terhadap nilai perusahaan

Ukuran perusahaan dilihat dari total aset. Besar kecilnya total aset pada perusahaan akan menggambarkan ukuran perusahaan. Semakin besar total aset maka semakin besar ukuran perusahaan, maka akan banyak menarik para investor untuk menanamkan modal. Hal ini disebabkan karena yang mempunyai total aset yang besar menggambarkan perusahaan itu stabil atau baik. Penelitian Fakhrana, dkk (2019) menghasilkan bahwa variabel ukuran perusahaan mempunyai pengaruh terhadap nilai perusahaan. Berdasarkan uraian tersebut maka dapat dirumuskan sebagai berikut:

\section{$\mathrm{H}_{4}$ : Ukuran Perusahaan berpengaruh terhadap}

\section{Nilai Perusahaan}

Kebijakan Deviden merupakan keputusan untuk menentukan berapa besar bagian dari pendapatan perusahaan akan dibagikan kepada para pemegang saham dan akan diinvestikasikan kembali atau di tahan dalam perusahaan. Kebijakan Deviden dapat diukur dengan DPR (Devidend Payout Ratio). Penelitian Senata M, (2016) mengahsilkan bahwa kebijakan deviden mempunyai pengaruh terhadap nilai perusahaan. Berdasarkan uraian tersebut maka dapat dirumuskan sebagai berikut:

$H_{5}$ : Kebijakan Deviden berpengaruh terhadap

Nilai Perusahaan

\section{METODE PENELITIAN}

Penelitian kuantitatif adalah penelitian yang berlandaskan pada filsafat positivisme. Digunakan untuk meneliti pada populasi atau sampel tertentu, pengumpulan data menggunakan Instrumen penelitian, analisis data bersifat kuantitatif atau statistik dengan tujuan untuk menguji hipotesis yang telah ditentukan. Sugiyono, (2012). Populasi yang digunakan dalam penelitian ini adalah perusahaan sektor industri barang konsumsi yang terdaftar di BEI periode 2015-2018. Pengambilan sampel dalam penelitian ini menggunakan metode purposive sampling dengan kriteria sampel : 1) Perusahaan Sektor Industri Barang Konsumsi yang terdaftar di BEI berturut-turut pada tahun 20152018. 2) Perusahaan Sektor Industri Barang Konsumsi yang tidak melaporkan annual report secara lengkapp selama tahun 2015-2018. 3) Perusahaan Sektor Industri Barang Konsumsi yang tidak membagikan dividen berturut-turut selama periode 2015-2018.

\section{Metode Analisis}

Uji Analisis yang digunakan pada penelitian ini yaitu uji Regresi Linier Berganda, yang digunakan untuk mengetahui pengaruh atau hubungan secara linier antara dua variabel independen (X) atau lebih dengan satu variabel dependen (Y) (Priyatno D. , 2014). Persamaan yang menyatakan bentuk hubungan anatara variabel $\mathrm{X}$ dengan $\mathrm{Y}$ disebut dengan persamaan regresi (Ghozali, 2011). Dengan hubungan secara linier variabel leverage (DER), profitabilitas (ROA) dan umur perusahaan dengan nilai perusahaan (PBV). Persamaan regresi linier berganda sebagai berikut:

$$
Y^{\prime}=a+b_{1} X_{1}+b_{2} X_{2}+b_{3} X_{3}+b_{4} X_{4}+b_{5} X_{5}+e
$$

Keterangan:

Y : Nilai Perusahaan a : Konstanta

b : Koefisien Regresi

$\mathrm{X}_{1}$ : Profitabilitas

$\mathrm{X}_{2}$ : Leverage

$\mathrm{X}_{3}$ : Likuiditas

$\mathrm{X}_{4}$ : Ukuran Perusahaan

$\mathrm{X}_{5}$ : Kebijakan Dividen

e : Error

\section{HASIL \& PEMBAHASAN}

Penelitian ini menggunakan data sekunder dengan populasi penelitian perusahaan sektor industri barang konsumsi yang terdaftar di Bursa Efek Indonesia periode 2015-2018. Pada penelitian ini menggunakan instrument dokumentasi berupa laporan keuangan yang didapat dari ww.idx.co.id. Pengambilan data pada penelitian in menggunakan metode purposive sampling, dengan kriteria yang 
sudah ditentukan. Dari kriteria yang sudah ditentukan terdapat 14 perusahaan dari 52 perusahaan. Data pengambilan sampel dapat dilihat pada tabel 2 sebagai berikut :

Tabel 1

Hasil Kriteria Sampel

\begin{tabular}{|c|c|}
\hline Keterangan & Jumlah \\
\hline 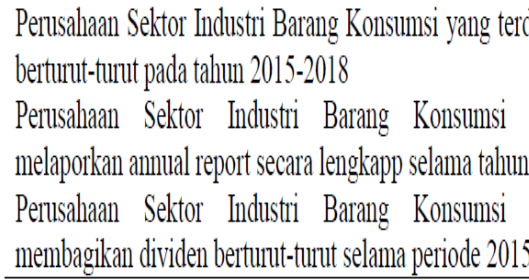 & (25) \\
\hline Jumlah sampel penelitian per periode penelitian & 14 \\
\hline Jumlah 0bservasi ( $14 \mathrm{X} 4$ tahun periode penelitian) & 56 \\
\hline Data Outlier & (14) \\
\hline Jumlah data vang diolah & 42 \\
\hline
\end{tabular}

Sumber: : Data diolah 2020

Tabel 2

\begin{tabular}{lccccc}
\multicolumn{5}{c}{ Hasil Uji Analisis Deskriptif } \\
Descriptive Statistics
\end{tabular}

Sumber : Data diolah 2020

Berdasarkan hasil statistik deskriptif pada tabel 3 dapat dilihat bahwa: Nilai minimum PBV 1,05 , nilai maksimum adalah 45,71 sedangkan nilai mean 5,2303 dan nilai standar deviasi 7,31743. Nilai minimum ROA 0,03 , nilai maksimum adalah 0,47 sedangkan nilai mean 0,1235 dan nilai standar deviasi 0,09060 . Nilai minimum DAR 0,07 , nilai maksimum adalah 1,32 sedangkan nilai mean 0,3731 dan nilai standar deviasi 0,21417 . Nilai minimum CR 0,75 , nilai maksimum adalah 8,64 sedangkan nilai mean 3,3156 dan nilai standar deviasi 2,06264. Nilai minimum SIZE 26,67, nilai maksimum adalah 32,20 sedangkan nilai mean 29,9370 dan nilai standar deviasi 1,53452. Dan nilai minimum DPR 0,20 , nilai maksimum adalah 1,13 sedangkan nilai mean 0,35002 dan nilai standar deviasi 0,23822.
Tabel3

Hasil Lji Asumsi Klasik

\begin{tabular}{llll}
\hline & $\begin{array}{l}\text { Unstandardized } \\
\text { Residual }\end{array}$ & Stancai & Keterangan \\
& & \\
\hline Asymp.Sig. (2-taled) & 0,200 & $>0,05$ & Nommal
\end{tabular}

Sumber : Data diolah 2020

Dari data tabel 3 hasil uji normalitas menunjukkan nilai signifikansinya sebesar 0,200 dimana nilai tersebut lebih besar dari 0,05 yang berarti bahwa data dinyatakan normal.

Tabel 4

Hasil Uji Multikolinieritas

\begin{tabular}{|c|c|c|c|c|c|c|}
\hline \multirow[b]{2}{*}{ Model } & & \\
\hline & $\begin{array}{l}\text { Toler } \\
\text { ance }\end{array}$ & $\begin{array}{l}\text { Standa } \\
\mathrm{r}\end{array}$ & VIF & $\begin{array}{l}\text { Standa } \\
\mathrm{r}\end{array}$ & Keterangan & \\
\hline Profitabilitas & 0,637 & $>0,1$ & 1,571 & $<10$ & $\begin{array}{l}\text { Tidak } \\
\text { Multikolinieritas }\end{array}$ & Terjadi \\
\hline Leverage & 0,559 & $>0,1$ & 1,790 & $<10$ & $\begin{array}{l}\text { Tidak } \\
\text { Multikolinieritas }\end{array}$ & Terjadi \\
\hline Likuiditas & 0,263 & $>0,1$ & 3,806 & $<10$ & $\begin{array}{l}\text { Tidak } \\
\text { Multikolinieritas }\end{array}$ & Terjadi \\
\hline Size & 0,405 & $>0,1$ & 2,467 & $<10$ & $\begin{array}{l}\text { Tidak } \\
\text { Multikolinieritas }\end{array}$ & Terjadi \\
\hline $\begin{array}{l}\text { Kebijakan } \\
\text { Dividen }\end{array}$ & 0,308 & $>0,1$ & 3,245 & $<10$ & $\begin{array}{l}\text { Tidak } \\
\text { Multikolinieritas }\end{array}$ & Terjadi \\
\hline
\end{tabular}

Sumber : Data diolah 2020

Dari tabel 4 hasil uji multikolinieritas menyatakan semua variabel independen mempunyai nilai $\mathrm{VIF}<10$ dan Tolerance $>0,1$. Maka dapat disimpulkan dari tabel diatas semua variabel independen tidak terjadi multikolinieritas.

Tabel5

Hasil Cji Autokorelasi

\begin{tabular}{cccc}
\hline & Unstandardized Residual & Standar & Keterangan \\
\hline Asymp.Sig. (2-tailed) & 0,274 & $>0,05$ & Data Normal \\
\hline Sumber: Data diolah 2020 & & &
\end{tabular}

Dari tabel 5 hasil Uji Autokorelasi menyatakan bahwa nilai sig 0,274 lebih besar dari nilai standar 0,05 . Maka dapat disimpulkan data tersebut normal.

Tabel 6

Hasil Uji Heteroskedastisitas

\begin{tabular}{llll}
\hline & Asymp.Sig. (2-tailed) & Standar & Keterangan \\
\hline X1 & 0,058 & $>0,05$ & Bebas Heteroskedastisitas \\
X2 & 0,526 & $>0,05$ & Bebas Heteroskedastisitas \\
X3 & 0,688 & $>0,05$ & Bebas Heteroskedastisitas \\
X4 & 0,733 & $>0,05$ & Bebas Heteroskedastisitas \\
X5 & 0,560 & $>0,05$ & Bebas Heteroskedastisitas \\
\hline \multicolumn{2}{l}{ Sumber : Data diolah 2020 }
\end{tabular}


Dari tabel 6 hasil uji heteroskedastisitas dapat dilihat bahwa semua variabel independen mempunyai nilai signifikansi lebih dari 0,05 . Sehingga dapat disimpulkan hasil dari tabel diatas bebas heteroskedastisitas.

Dari hasil data uji regresi dapat terbentuk sebagai berikut:

$$
\begin{aligned}
& Y=0,781+90,529 X_{1}-0,827 X_{2}-0,964 X_{3}+ \\
& 0,053 X_{4}-9,608 X_{5}+e
\end{aligned}
$$

Dari hasil data uji regresi diatas, dapat diketahui nilai konstanta yang sebesar0,781. jadi apabila Profitabilitas, leverage, likuiditas, ukuran perusahaan dan kebijakan dividen $(\mathrm{X} 1, \mathrm{X} 2, \mathrm{X} 3, \mathrm{X} 4, \mathrm{X} 5)=0$ maka tidak terdapat kenaikan pada Nilai Perusahaan atau sama dengan 0,781. Nilai Profitabilitas sebesar $\beta 1$ 90,529 yang berarti jika profitabilitas naik sebesar 1 satuan maka nilai leverage akan bertambah sebesar 90,529 kali dengan variable bebas lainnya konstan. Nilai Leverage sebesar $\beta 2-0,827$ yang berarti jika leverage naik sebesar 1 satuan maka nilai leverage akan menurun sebesar -0,827 kali dengan variable bebas lainnya konstan. Nilai likuiditas $\beta 3-0,964$ yang berarti jika umur perusahaan naik sebesar 1 satuan maka nilai likuiditas akan menurun sebesar $-0,964$ kali dengan variable bebas lainnya konstan. Nilai ukuran perusahaan $\beta 40,053$ yang berarti jika ukuran perusahaan naik sebesar 1 satuan maka nilai ukuran perusahaan akan bertambah sebesar 0,053 kali dengan variable bebas lainnya konstan. Nilai kebijakan dividen $\beta 5-9,608$ yang berarti jika umur perusahaan naik sebesar 1 satuan maka nilai kebijakan dividen akan menurun sebesar -9,608 kali dengan variable bebas lainnya konstan.

Tabel 7

Hasil Uji F

Model FhitungFtabelSig. Standar Keterangan 1

Regression 62,480 >2,63 0,00<0,05 Model layak Sumber : Data diolah 2020

Dari tabel 7 hasil uji $\mathrm{F}$, dapat diketahui bahwa Fhitung sebesar 62,480 hasil tersebut dibandingkan Ftabel sebesar 2,63. Karena Fhitung $>$ Ftabel $(62,480>2,63)$ dengan nilai signifikansi 0,000 dimana lebih kecil dari 0,05 sehingga dapat disimpulkan profitabilitas, leverage, likuiditas, ukuran perusahaan dan kebijakan berpengaruh signifikan terhadap nilai perusahaan.
Tabel 8

\begin{tabular}{|c|c|c|c|c|c|}
\hline \multirow{2}{*}{$\begin{array}{l}\text { Hipotesi } \\
\mathrm{s}\end{array}$} & \multicolumn{3}{|l|}{$\mathrm{T}$} & \multicolumn{2}{|c|}{ Standa Keteranga } \\
\hline & hitung & $\mathrm{T}$ tabel & Sig. & $\mathrm{r}$ & $\mathrm{n}$ \\
\hline & 16,69 & $>1,6870$ & 0,00 & & \\
\hline H1 & 5 & 9 & 0 & $<0,05$ & Diterima \\
\hline & & $>1,6870$ & 0,73 & & \\
\hline $\mathrm{H} 2$ & $-0,338$ & & 8 & $<0,05$ & Ditolak \\
\hline & & $>1,6870$ & 0,01 & & \\
\hline H3 & $-2,599$ & 9 & 3 & $<0,05$ & Diterima \\
\hline & & $<1,6870$ & 0,89 & & \\
\hline H4 & 0,896 & 9 & 6 & $<0,05$ & Ditolak \\
\hline & & $>1,6870$ & 0,00 & & \\
\hline H5 & 0,003 & 9 & 3 & $<0,05$ & Diterima \\
\hline
\end{tabular}
Hasil Uji Hipotesis

Sumber : Data diolah 2020

Dapat dilihat pada tabel 8 bahwa semua variabel independen pada penelitian ini memiliki $t_{\text {hitung }}>t_{\text {tabel }}$ dan nilai signifikansi $<0,05$. Dinyatakan bahwa variabel profitabilitas, likuiditas, dan kebijakan dividen dinyatakan diterima, sedangkan variabel leverage dan size dinyatakan ditolak.

Tabel 9

\begin{tabular}{|c|c|c|}
\hline Model & $\begin{array}{l}\text { Adjusted } \\
\text { Square }\end{array}$ & $\mathrm{R}$ Keterangan \\
\hline 1 & 0,882 & $\begin{array}{l}\text { variabel profitabilitas, leverage, likuiditas, } \\
\text { ukuran perusahaan dan kebijakan } \\
\text { dividendan secara simultan berpengarvh } \\
\text { terhadap variabel nilai perusahaan sebesar } \\
88,2 \%\end{array}$ \\
\hline
\end{tabular}

Uji Koefisien Determinasi

Sumber : Data diolah 2020

Dari tabel 9 dapat dilihat hasil uji koefisien determinasi yang menyatakan nilai adjusted square sebesar 0,882 (88,2\%). Maka dapat diartikan nilai perusahaan dipengaruhi variabel independen (profitabilitas, leverage, likuiditas, ukuran perusahaan dan kebijakan dividen) sebesar $88,2 \%$. Dan untuk sisanya sebesar $11,8 \%$ nilai perusahaan dipengaruhi oleh faktor-faktor lain diluar variabel independen pada penelitian ini.

\section{PEMBAHASAN}

Pada penelitian ini dapat ditemukan bukti empiris mengenai Profitabilitas, Leverage, Likuiditas, Ukuran Perusahaan dan Kebijakan Dividen terhadap Nilai Perusahaan pada tahun 2015-2018 dengan objek penelitian adalah perusahaan sektor industri barang konsumsi yang terdaftar di Bursa Efek Indonesia (BEI) tahun 2015-2018. Hasil pengujian hipotesis ini 
menunjukkan bahwa Leverage dan ukuran perusahaan tidak berpengaruh terhadap nilai perusahaan. Sedangkan Profitabilitas, Likuiditas, dan Kebijakan Dividen berpengaruh terhadap nilai perusahaan.

Profitabilitas berpengaruh terhadap nilai perusahaan. Sejalan dengan hasil penelitian yang dilakukan (Wardoyo, 2013), (Wahyudi, 2016) yang menyatakan bahwa profitabilitas berpengaruh signifikan terhadap nilai perusahaan. Dengan profitabilitas yang tinggi dalam suatu perusahaan akan meningkatkan harga saham. Hal ini berdampak ke investor dalam melakukan investasi, sebelum menentukan dimana investor melakukan suatu investasi saham, investor akan melihat laporan kinerja perusahaan tersebut, salah satunya kinerja profitabilitas perusahaan, semakin besar tingkat profitabilitas perusahaan, maka semakin tinggi harga saham, sehingga akan menambah daya tarik investor dalam melakukan investasinya.

Leverage tidak berpengaruh terhadap nilai perusahaan. Sejalan dengan penelitian (Saxena, 2016), (Lestari,2016) dalam hasil ini menunjukan leverage tidak berpengaruh terhadap nilai perusahaan. Artinya, perusahaan dalam mendanai aktivanya cenderung menggunakan modal saham daripada menggunakan modal sendiri yang berasal dari laba ditahan dan modal saham dari pada menggunakan hutang. Kecukupan dana yang dimiliki perusahaan untuk membiayai aktivanya yang diperoleh dari modal sendiri membuat perusahaan mengurangi proporsi hutangnya. Penggunaaan hutang yang berlebihan akan mengurangi manfaat yang diterima atas penggunaan hutang karena manfaat yang diterima tidak sebanding dengan biaya yang ditimbulkan.

Likuiditas berpengaruh terhadap nilai perusahaan. Sejalan dengan penelitian (Agustina dan Wijaya, 2013) menyatakan bahwa variabel likuiditas secara parsial berpengaruh terhadap nilai perusahaan. Likuiditas menggambarkan kemampuan perusahaan dalam memenuhi kewajiban jangka pendeknya yang segera harus dipenuhi pada saat ditagih untuk mempertahaan likuiditasnya. Rasio likuiditas merupakan kemampuan perusahaan untuk memenuhi atau membayar kewajiban jangka pendeknya secara tepat waktu.

Ukuran Perusahaan tidak berpengaruh terhadap nilai perusahaan. Hasil penelitian didukung oleh penelitian (Pratiwi,2017) ukuran perusahaan dinilai dari total aset yang dimiliki oleh perusahaan untuk kegiatan operasionalnya, semakin besar ukuran perusahaan akan semakin besar juga besar pula dana yang dibutuhkan untuk kegiatan operasionalnya.

Kebijakan Dividen berpengaruh terhadap nilai perusahaan. Penelitian (Fakhrana, Yetty, \& Bambang , 2019) menyatakan bahwa kebijakan dividen berpengaruh signifikan terhadap nilai perusahaan. Dengan nilai dividen yang tinggi maka pembagian saham akan tinggi sebaliknya dengan nilai kebijakan yang rendah maka kemungkinan tidak ada pembagian saham atau bisa jadi dana dicadangkan untuk membiayai perusahan ditahun berikutnya. Dengan besarnya dividen yang dibagikan kepada pemegang saham akan menjadi daya tarik bagi pemegang saham karena sebagian investor cenderung menyukai dividen.

\section{KESIMPULAN}

Tujuan penelitian untuk mengetahui: 1) Mengetahui dan menganalisis pengaruh profitabilitas terhadap nilai perusahaan. 2) Mengetahui dan menganalisis pengaruh leverage terhadap nilai perusahaan.3) Mengetahui dan menganalisis pengaruh likuiditas terhadap nilai perusahaan.4) Mengetahui dan menganalisis pengaruh ukuran perusahaan terhadap nilai perusahaan. 5) Mengetahui dan menganalisis pengaruh kebijakan dividen terhadap nilai perusahaan. Populasi yang digunakan dalam penelitian ini adalah perusahaan sektor industri barang dan konsumsi yang terdaftar di BEI periode 2015-2018, dengan metode purposive sampling mendapatkan 14 sampel perusahaan yang dapat digunakan.dengan menggunakan analisis linier berganda menghasilkan bahwa variabel profitabilitas, leverage, ukuran perusahaan dan kebijakan dividen berpengaruh terhadap nilai perusahaan sedangkan variabellikuiditas tidak berpengaruh terhadap nilai perusahaan.

Keterbatasan pada penelitian ini : variabel yang digunakan hanya lima variabel independen yaitu profitabilitas, leverage, likuiditas, ukuran perusahaan dan kebijakan deviden. Penelitian ini juga hanya menggunakan 14 perusahaan sektor industri barang dan konsumsi yang terdaftar dibursa efek indonesia yang memenuhi kriteria penelitian untuk periode penelitian tahun 20152018.

Berdasarkan hasil penelitian, kesimpulan dan hal-hal yang berkaitan dengan keterbatasan, maka saran yang diberikan peneliti selanjutnya diharapkan untuk menambah variabel-variabel lainya yang berpengaruh terhadap nilai 
perusahaandan dapat mengembangkan penelitian pada perusahaan lain yang terdaftar di BEI agar tidak fokus hanya pada perusahaan industri barang konsumsi dan menambah periode tahun penelitian. Bagi perusahaan diharapkan perusahaan yang menjadi subjek penelitian maupun perusahaan lainnya yang tiidak termasuk subjek dapat meningkatkan dan memaksimalkan nilai perusahaan dengan cara lebih memperhatikan kinerja perusahaan dan tata kelola perusahaan dalam menghasilkan laba perusahaan agar terus meningkat dan terhindar dari kerugian, dan dapat mengalihkan dana perusahaan kedalam investasi yang dapat menguntungkan perusahaan. Dan bagi investor diharapakan investor dapat memperhatikan kondisi perusahaan sebelum menanamkan modalnya agar mendapatkan pengembalian modal yang sesuai dengan perjanjian. Lebih memperhatikan juga struktur modal pada perusahaan sebelum menanamkan modal, karena struktur modal pada perusahan dapat menjadi penentuan tingkat nilai perusahaan yang baik atau tidak.

\section{DAFTAR PUSTAKA}

Adenugba , A. A., Ige, A., \& Kesinro, O. (2016). Financial Leverage and Firm's Value: A Study of Selected Firms In Nigeria . European Journal of Research and Reflection in Management Sciences, 14-32.

Andreas , N., \& Joy, E. T. (2018). Pengaruh Kebijakan Dividen, Keputusan Pendanaan Dan Keputusan Investasi Terhadap Nilai Perusahaan Pada Saham Bluechip Yang Terdaftar Di BEI. Jurnal EMBA, 28782887.

Andriani, P. R. (2019). Pengaruh Tingkat Likuiditas, Profitabilitas Dan Leverage Terhadap Nilai Perusahaan Pada Subsektor Makanan Dan Minuman Yang Tercatat Di BEI Periode 2010-2017. Journal of Entrepreneurship, Management and Industry (JEMI), 48-60.

Angelina , G., \& Widyasari. (2019). Pengaruh Capital Structure, Profitability, Firm Size, Dan Firm Growth Terhadap Firm Value . Jurnal Multiparadigma Akuntansi, 255-262.

Aniela, N., Deannes, I., \& Annisa, N. (2017). Pengaruh Profitabilitas, Leverage, Dan Ukuran Perusahaan Terhadap Nilai Perusahaan. e-Procedding of Management, 542.
Aryanto, U. R., Titisari, H. K., \& Nurlaela, S. (2018). Pengaruh likuiditas, leverage, profitabilitas, dan aktivitas terhadap pertumbuhan laba . Seminar Nasional Lenaco, 625-631.

Asmaul, H., \& Ibnu, S. (2019). Effect of Return on Asset, Debt to Asset Ratio, Current Ratio, Firm Size, and Dividen Payout Ratio on Firm Value. International Journal of Economics and Financial Issues, 50-54.

Barney.J. (1991). Firm Resources and sustained competitive advantage . Journal Management, 99-120.

Blinch, J., Mccarron, B., \& Carmody, L. (2011). The future of fish in Asia. Trends in Ecology and Evolution, 594-599.

Brigham, F., Eugene, \& Houston, J. (2010). Dasar dasar manajemen keuangan . Jakarta: Salemba Empat.

Brigham, \& Houston. (2001). Manajemen Keuangan. Jakarta: Erlangga.

Brigham, Eugene, F., \& Joel, F. H. (2001). Manajemen Keuangan . Jakarta: Erlangga.

Dewi, Inggi, Siti, R., \& Nila , F. (2014). Pengaruh Struktur Modal terhadap Nilai Perushaan Pertambangan yang Terdaftar di BEI Periode 2009-2012. Jurnal Administrasi Bisnis , 1-9.

DR. Sanjay, R., \& Dr. Pradeep, S. (2016). Leverage and Firms Value: An Emperical Review Of Concept With Reference To High Leveraged Indian Compaines. International Journal of Research in IT and Mangement (IJRIM), 99-104.

Ernawati, D., \& Widyawati, D. (2015). Pengaruh Profitabilitas, leverage, dan ukuran perusahaan terhadap nilai perusahaan. Jurnal Ilmu \& Riset Akuntansi, 1-17.

Etti , E. S., \& Rosma, P. (2010). Pengaruh Kebijakan Dividen Terhadap Nilai Perusahaan Pada Perusahaan Manufaktur Yang Terdaftar DI Bursa Efek Indonesia. Jurnal Ekonomi, Keuangan, Perbankan dan Akuntansi, 47-56.

Fakhrana, O., Yetty, M., \& Bambang, S. (2019). Pengaruh

Profitabilitas,Likuiditas,Leverage,Kebijakan Dividen Dan Ukuran Terhadap Nilai Perusahaan. Jurnal Akuntansi, 1-16.

Fakhrana, O., Yetty, M., \& Bambang, S. (2019). Pengaruh Profitabilitas, Likuiditas, Leverage, Kebijakan Dividen Dan Ukuran Terhadap Nilai Perusahaan. Jurnal Akuntansi, 1-16. 
Ghozali,

$\begin{array}{lll}\text { I. (2011). } & \text { Aplikasi } & \text { Analisis } \\ \text { Multivariate } & \text { Dengan } & \text { Program } \\ \text { Ibm } & \text { Spss } & 20 .\end{array}$

Surakarta: Uniba Perss.

Gultom, R., Agustina, \& Wijaya, S. W. (2013). Analisis faktor-faktor yang mempengaruhi nilai perusahaanpada perusahaan farmasi di Bursa Efek Indonesia. Jurnal Wira Ekonomi Mikroskil.

Houston, B. (2006). Dasar Dasar Manajemen Keuangan. Thomson South Western.

Husnan, S. (2000). Manajemen Keuangan-Teori dan Peneraoan (Keputusan Jangka Panjang). Yogyakarta: Bpfe.

I Putu, S., \& I Gede, K. B. (2019). Pengaruh Profitabilitas, Leverage, Dan Likuiditas Terhadap Nilai Perusahaan Sub Sektor Food And Beverage. E-Jurnal Manajemen, 73997428.

Indriyani, E. (2017). Pengaruh Ukuran Perusahaan dan Profitabilitas Terhadap Nilai Perusahaan. Jurnal Ilmu Akuntansi, 333348.

Irawati, S. (2006). Manajemen Keuangan . Bandung : Pustaka.

Kasmir. (2013). Pengantar Manajemen Keuangan. Jakarta: Kencana Prenada Media Group.

Lidya, M., Nur, U. S., Maria, M., Febsri, S., \& Yulia, S. (2018). Profitabilitas dan Kebijakan Deviden Terhadap Nilai Perusahaan. Jurnal Benefita, 227-238.

Marfuah, S. A., \& Nurlaela, S. (2017). Pengaruh Ukuran Perusahaan, Pertumbuhan Aset, Profitabilitas dan Pertumbuhan Penjualan Terhadap Struktur Modal Perusahaan Cosmetics and Houshold di Bursa Efek Indonesia . Jurnal Akuntansi Dan Pajak, 1630.

Mohammad , F. E., Rony, M. M., \& Budi , W. (2017). Pengaruh Kebijakan Dividen, Kebijakan Utang Dan Profitabitas Terhadap Nilai Perusahaan Studi Kasus Pada Perusahaan Yang Terdaftar Di Jakarta Islamic Index Periode 2013-2016. e-jurnal riset Manajemen, 92-105.

Mukhammad, A., \& Mochammad Chabachib. (2016). Analisis Faktor Faktor Yang Mempengaruhi Nilai Perusahaan (Studi kasus pada perusahaan yang terdaftar pada Indeks LQ-45 Periode 2011-2014). Diponegoro Journal Of Management, 23373792.

Mulyani, S., Wijayanti, A., \& Masitoh, E. (2018). Pengaruh Corporate Governance Terhadap
Tax Avoidance. Jurnal Riset Akuntansi Dan Bisnis Airlangga.

Nurlaela, r., \& islaudin. (2007). pengaruh corporate social responcibility terhadap nilai perusahan dengan prosentasi kepemilikan manajemen sebagai variabel moderating . universitas syah kuala.

Nurmayasari, \& Andi. (2012). Analisis Pengaruh Profitabilitas, Ukuran Perusahaan, Leverage, Dan Kebijakan Deviden Terhadap Nilai Perusahaan.

Priya, V. P., \& Mohanasundari, M. (2016). Devidend Policy and Its Impact on Firm Value. Departement of management studies.

Riny. (2018). Analisis Faktor-Faktor Yang Mempengaruhi Nilai Perusahaan Pada Perusahaan Consumer Goods Yang Terdaftar Di Bursa Efek Indonesia. JWEM STIE MIKROSKIL, 139-150.

Safrida, E. (2010). Pengaruh Struktur Modal, Pertumbuhan Perusahaan, Profitabilitas Dan Ukuran Perusahaan Terhadap Nilai Perusahaan. Jurnal Akuntansi Riset, 553568.

Sambora, M. N., Handayani, S. R., \& Rahayu, S. M. (2014). Pengaruh Leverage dan Profitabilitas Terhadap Nilai Perusahaan. Jurnal Administrasi Bisnis (JAB), 1-10.

Sari, M. R., \& Handayani, N. (2016). Pengaruh Profitablitas, Ukuran Perusahaan, dan Leverage Terhadap Nilai Perusahaan Transportasi. Jurnal Iilmu dan Riset Akuntansi, 1-18.

Selin, L., Sri , M., \& Victoria, N. U. (2018). Pengaruh Likuiditas, Ukuran Perusahaan Dan Profitabilitas Terhadap Nilai Perusahaan. Jurnal EMBA, 1108-1117.

Selin, L., Sri, M., \& Victoria , N. U. (2018). Pengaruh Likuiditas, Ukuan Perusahaan Dan Profitabilitas Terhadap Nilai Perusahaan. Jurnal EMBA, 1108-1117.

Senata, \& Maggee. (2016). Pengaruh Kebijakan Deviden Terhadap Nilai Perusahaan Yang Tercatat Pada Indeks LQ-45 Bursa Efek Indonesia . Jakarta: Salemba Empat.

Senata, M. (2016). Pengaruh Kebijakan Dividen Terhadap Nilai Perusahaan Yang Tercatat Pada Indeks LQ-45 BEI. Jurnal Wira Ekonomi Mikroskil , 73-84.

Siahaan, E., Gultom, P., \& Lumbanraja, P. (2016). Improvement of employee banking performance based on competency improvement and placement working through career development (case study in 
Indonesia). Internasional Business Management, 255-261.

Sugiyono. (2012). Metode Penelitian Kuantitatif dan Kualitatif dan $R \& D$. Bandung : Alfabeta.

Sugiyono. (2013). Statistik Untuk Penelitian . Bandung: Alfabeta.

Sujoko, \& Soebiantoro , U. (2007). Pengaruh Struktur Kepemilikan Saham, Leverage, Faktor Intern dan Faktor Ekstern Terhadap Nilai Perusahaan. Jurnal Manajemen Dan Kewirausahaan , 41-48.
Wahyudi, H. D. (2016). Pengaruh ukuran perusahaan, profitabilitas, kebijakan dividen dan keputusan investasi terhadap nilai perusahaan.

Wardoyo. (2013). Pengaruh Good Corporate Governance, Corporate Social Reponsibility dan Kinerja Keuangan Terhadap Nilai Perusahaan. Jurnal Dinamika Manajemen, 132-149.

Weston, J., Fred, \& Thomas , E. (2010). Dasar-

Dasar Manajemen Keuangan. Jakarta: Erlangga. Wild, S., \& Hasley. (2005). Analisi laporan keuangan .edisi kedelapan. Jakarta: Salemba Empat. 